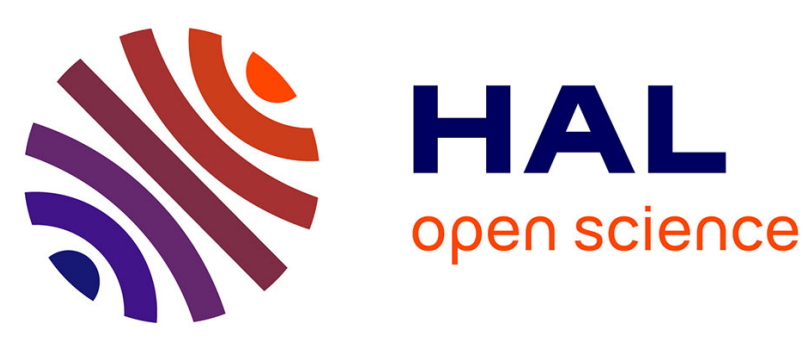

\title{
Delayed degradation in soil of foliar herbicides glyphosate and sulcotrione previously absorbed by plants: Consequences on herbicide fate and risk assessment
}

Jeremy Doublet, Laure Mamy, Enrique Barriuso

\section{To cite this version:}

Jeremy Doublet, Laure Mamy, Enrique Barriuso. Delayed degradation in soil of foliar herbicides glyphosate and sulcotrione previously absorbed by plants: Consequences on herbicide fate and risk assessment. Chemosphere, 2009, 77 (4), pp.582-589. 10.1016/j.chemosphere.2009.06.044 . hal01192111

\section{HAL Id: hal-01192111 \\ https://hal.science/hal-01192111}

Submitted on 30 May 2020

HAL is a multi-disciplinary open access archive for the deposit and dissemination of scientific research documents, whether they are published or not. The documents may come from teaching and research institutions in France or abroad, or from public or private research centers.
L'archive ouverte pluridisciplinaire HAL, est destinée au dépôt et à la diffusion de documents scientifiques de niveau recherche, publiés ou non, émanant des établissements d'enseignement et de recherche français ou étrangers, des laboratoires publics ou privés. 


\title{
Delayed degradation in soil of foliar herbicides glyphosate and sulcotrione previously absorbed by plants: Consequences on herbicide fate and risk assessment
}

\author{
Jérémy Doublet, Laure Mamy**, Enrique Barriuso \\ INRA (Institut National de la Recherche Agronomique) - AgroParisTech, UMR 1091 Environnement et Grandes Cultures, 78850 Thiverval-Grignon, France
}

\section{A R T I C L E I N F O}

\section{Article history:}

Received 16 April 2009

Received in revised form 16 June 2009

Accepted 17 June 2009

Available online 21 July 2009

\section{Keywords:}

Pesticide fate

Mineralization

Non-extractable (bound) residues

Oilseed rape

Maize

\begin{abstract}
A B S T R A C T
Following application, pesticides can be intercepted and absorbed by weeds and/or crops. Plants containing pesticides residues may then reach the soil during the crop cycle or after harvest. However, the fate in soil of pesticides residues in plants is unknown. Two commonly used foliar herbicides, glyphosate and sulcotrione, ${ }^{14} \mathrm{C}$-labeled, were applied on leaves of oilseed rape and/or maize, translocation was studied, and then soil incubations of aerial parts of plants containing herbicides residues were performed. Soil treated directly with herbicides was used as control. The effects of adjuvants on herbicide plant-absorption and subsequent soil-degradation were also investigated comparing herbicides application as active ingredients and as commercial formulations. The fate in soil of herbicides residues in plants was different from that of control, and different for glyphosate and sulcotrione. Mineralization in soil of glyphosate in crops decreased compared to control, and amounts of ${ }^{14} \mathrm{C}$-extractable residues, mainly composed by the metabolite aminomethylphosphonic acid (AMPA), and non-extractable residues (NER) increased. In contrast, mineralization in soil of sulcotrione in maize increased compared to control, with a decrease in the ${ }^{14} \mathrm{C}$-extractable residues and an increase in NER. The fate of both herbicides was influenced by the type of plant organ in which herbicide was incorporated, because of differences in herbicides bioavailability and organs biodegradability, but not by adjuvants. Absorption of both herbicides in plant delays their subsequent soil-degradation, and particularly, glyphosate persistence in soil could increase from two to six times. The modifications of herbicide degradation in soil due to interception by plants should be considered for environmental risks assessment.
\end{abstract}

(c) 2009 Elsevier Ltd. All rights reserved.

\section{Introduction}

Following application, most pesticides reach the soil, due to direct application and/or after foliage washoff (Torstensson, 1985). However, amounts of pesticides, particularly in case of foliar pesticides, are intercepted and absorbed by the leaves of weeds and/or crops. Plants containing pesticides may return to soil during the crop cycle (leaf senescence) or after harvest in crop residues form. The fate in soil of pesticide residues in plant material is generally ignored and not known. The pesticide and/or its degradation products could be released in soil during the plant decomposition with a delayed contribution of these substances to soil and an additional risk of environmental contamination.

To investigate the fate in soil of plant-absorbed pesticide, two commonly used foliar herbicides were selected: glyphosate ([N(phosphonomethyl)glycine]), a broad spectrum post-emergence herbicide used for control of annual and perennial grasses and

\footnotetext{
* Corresponding author. Present address: INRA, UR 251 Physicochimie et Ecotoxicologie des Sols d'Agrosystèmes Contaminés, 78026 Versailles, France. Tel.: +33 (0) 130833108 .

E-mail address: laure.mamy@versailles.inra.fr (L. Mamy).
}

dicotyledonous weeds (Franz, 1985), and sulcotrione (2-[2chloro-4-(methylsulfonyl)benzoyl]-1,3-cyclohexanedione), a postemergence maize selective herbicide used for control of a broad range of broadleaf weeds and some annual grasses (Wilson and Foy, 1990).

The degradation of these herbicides applied on soil is well known. Glyphosate degradation in soil is mainly biological with laboratory half-lives (DT50) ranging from less than 1 day to 40 days (Rueppel et al., 1977; Smith and Aubin, 1993; Mamy et al., 2005). The main metabolite of glyphosate is aminomethylphosphonic acid (AMPA) which is more persistent: DT50 ranged from 25 to 75 days (Mamy et al., 2005). Sulcotrione degradation in soil is also mainly biological with DT50 ranging from 2 to $<60$ days (Cherrier et al., 2004; Mamy et al., 2005), but photodegradation can play an important role (Ter Halle et al., 2006). Its main degradation product in soil is 2-chloro-4-methylsulfonylbenzoic acid (CMBA) with DT50 ranging from 46 to 71 days (Mamy et al., 2005).

The amounts of herbicide residue in plant material which will enter the soil depend on absorption, translocation and degradation of active ingredient (a.i.) in treated plants (Gauvrit, 1996; Grangeot et al., 2006). For glyphosate, the absorption and translocation in 
plants is related to species (Sandberg et al., 1980), development stage of plant (Ahmadi et al., 1980), amounts of a.i. applied (Hetherington et al., 1999; Leaper and Holloway, 2000), presence of adjuvants in solution (Leaper and Holloway, 2000), and environmental factors like temperature and light (Coupland, 1983). Glyphosate is rapidly absorbed by foliage and translocates to developing apical and root meristems (Grangeot et al., 2006); its degradation in plants varies according to species but is generally low (Sandberg et al., 1980; Caseley and Coupland, 1985; Marshall et al., 1987; Lorraine-Colwill et al., 2002). A particular behavior can be expected when glyphosate is absorbed by genetically modified glyphosateresistant plants. Little data have been published regarding the degradation in soil of glyphosate residues in plants. A study where glyphosate was associated with soybean cells has shown that its fate was different than application on soil: mineralization experienced a lag phase and non-extractable residues (NER) increased (Von Wiren-Lehr et al., 1997). For sulcotrione, very few data have been published in the literature. The absorption of sulcotrione by foliage of maize and soybean is higher than by roots; the translocation is rapid with accumulation of the herbicide in shoots and new growth (Armel et al., 2004). To our knowledge, no other data are available, neither concerning the fate in soil of sulcotrione residues in crops or weeds.

The objective of this work was to study the fate in soil of glyphosate and sulcotrione residues contained in the aerial parts of oilseed rape and maize. To evaluate amounts of herbicide incorporated in soil with plant materials, we first studied absorption, translocation and degradation of glyphosate and sulcotrione in the two crops. Then, laboratory incubations of soil with different aerial parts of crops containing herbicides were performed.

\section{Materials and methods}

\subsection{Herbicides}

[Methyl- ${ }^{14} \mathrm{C}$ ]glyphosate was purchased from Sigma Chemicals (St. Louis, USA; $81 \mathrm{MBq} \mathrm{mmol}^{-1}, 99.2 \%$ purity) and [U-phenyl- ${ }^{14} \mathrm{C}$ ]sulcotrione from Izotop (Budapest, Hungary; $47 \mathrm{MBq} \mathrm{mmol}^{-1}, 91 \%$ purity). Solutions of labeled herbicides were obtained by isotopic dilution with non-labeled herbicides (analytical standards, $>98 \%$ purity) at $7.2 \mathrm{~g} \mathrm{~L}^{-1}$ (in water, containing $0.157 \mathrm{MBq} \mathrm{mL}^{-1}$ ) for ${ }^{14} \mathrm{C}$-glyphosate, and $4.8 \mathrm{~g} \mathrm{~L}^{-1}$ (in water/methanol $40 / 60 \mathrm{v} / \mathrm{v}$ because the solubility of sulcotrione in water is $0.165 \mathrm{~g} \mathrm{~L}^{-1}$, containing $0.119 \mathrm{MBq} \mathrm{mL}{ }^{-1}$ ) for ${ }^{14} \mathrm{C}$-sulcotrione. Solutions in water were also prepared with commercial products: Roundup ${ }^{\circledR}$ Biovert 360 (360 $\mathrm{g} \mathrm{L}^{-1}$, Monsanto) for glyphosate (final concentration of $\left.7.2 \mathrm{~g} \mathrm{~L}^{-1}, 0.162 \mathrm{MBq} \mathrm{mL}^{-1}\right)$, and Mikado ${ }^{\circledR}\left(300 \mathrm{~g} \mathrm{~L}^{-1}\right.$, Bayer CropScience) for sulcotrione (final concentration of $4.8 \mathrm{~g} \mathrm{~L}^{-1}, 0.119$

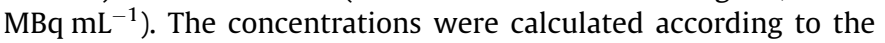
recommendations of commercial products, taking into account the maximum authorized doses and a low sprayed volume per hectare (from 100 to $150 \mathrm{~L}$ ). The effect of the dose on the fate of glyphosate in soil was investigated with a twenty times lower concentration of glyphosate solution $\left(0.38 \mathrm{~g} \mathrm{~L}^{-1}\right.$ and $\left.0.187 \mathrm{MBq} \mathrm{mL}^{-1}\right)$.

\subsection{Plant material}

Oilseed rape (Brassica napus L.) was sowed in one-litre pots filled with commercial growing substrate (90\% peat substrate $+10 \%$ clay, Floradur B, Puteaux SA Fournitures horticoles, Les Clayes sous Bois, France) and was grown to 4-7 leaves stage in an experimental greenhouse under natural sunlight (photoperiod of $13 \mathrm{~h}$ day and $11 \mathrm{~h}$ night) at $20 \pm 1^{\circ} \mathrm{C}$. Maize (Zea mais L.) was sampled from an agricultural field at the 5 leaves stage in May, then transplanted in 1-L pots filled with the Floradur B sub- strate. For each crop, 60 replicates were done and only one plant was left per pot.

\subsection{Soil}

Soil samples were taken from the top layer $(0-10 \mathrm{~cm})$ of a French experimental site (Dijon, Burgundy), immediately placed in a cooler and taken to the laboratory where they were passed through a $3 \mathrm{~mm}$ sieve and stored at $4{ }^{\circ} \mathrm{C}$ for 8 days before use. The soil is a clay-loam calcareous Cambisol with $37.7 \%$ of clay $(<2 \mu \mathrm{m}), 29.6 \%$ of silt $(2-50 \mu \mathrm{m}), 15.2 \%$ of sand $(50-200 \mu \mathrm{m})$, $16.7 \%$ of $\mathrm{CaCO}_{3}, 1.63 \%$ of organic carbon, $\mathrm{pH}$ in water of 8.2 , and water field capacity of $26.1 \%$ (determined at $-1000 \mathrm{hPa}$ ).

\subsection{Absorption and translocation of herbicides in plants}

Ten $5 \mu \mathrm{L}$ droplets of glyphosate or sulcotrione solutions were applied on the second youngest leaf of oilseed rape and/or maize plants using a $25-\mu \mathrm{L}$ micro-syringe (Hamilton Co, Alltech, Deerfield, IL, USA) (Chamel et al., 1991). The plants development was: 4 and 7 leaves of oilseed rape for application of glyphosate in water and in Roundup, respectively, and 5 and 7 leaves of maize for glyphosate and sulcotrione, respectively. Absorption of glyphosate and sulcotrione in plants was evaluated 1 and 7 days after treatment (DAT) by washing each treated leaf with $10 \mathrm{~mL}$ of water then with $10 \mathrm{~mL}$ of an acetone/water solution (1:1) (Grangeot et al., 2006). Amounts of absorbed herbicide were estimated by the difference between radioactivity contained in wash solution, determined by liquid scintillation counting, and the applied radioactivity. In addition, 7 DAT, lamina, apex, petiole and stem of plants were isolated and extracted once with water $(10 \mathrm{~mL}$ for apex and petiole, $20 \mathrm{~mL}$ for lamina) for $24 \mathrm{~h}$, then three times for 6,15 and 6 h with $0.54 \mathrm{M} \mathrm{NH}_{4} \mathrm{OH}$. Herbicide translocation in plants was evaluated by ${ }^{14} \mathrm{C}$ measurements after combustion (see Chemicals analysis) of different parts of the plants. The role of commercial product on herbicides absorption, translocation and degradation was investigated with solutions that did or did not contain commercial formulation. Three replicates were done for each experiment.

\subsection{Incubation procedure}

Seven DAT, treated leaves were washed (see above), then different aerial parts of plants (lamina, apex, petiole and stem) were incorporated into 11.4 or $57 \mathrm{~g}$ soil corresponding to 10 or $50 \mathrm{~g}$ dry soil ( $11.4 \mathrm{~g}$ for oilseed rape apex, $57 \mathrm{~g}$ for oilseed rape lamina and petiole and maize lamina and stem). The mass of soil needed was determined to obtain an average plant/soil ratio of $3 \mathrm{~g} \mathrm{~kg}^{-1}$ representative of crop restitution to soil (Johnson et al., 2006). Controls were performed with $50 \mu \mathrm{L}$ of each herbicide solution (including low concentration of glyphosate) applied directly on $10 \mathrm{~g}$ dry soil. The soil and plants were then placed in $500 \mathrm{~mL}$ hermetically stoppered jars and incubated in darkness for 35 days at $28 \pm 1{ }^{\circ} \mathrm{C}$. Water was added to reach a soil moisture content equivalent to field capacity. Each jar contained a vial with $2 \mathrm{~mL}$ of $2 \mathrm{M}$ $\mathrm{NaOH}$ to trap evolved ${ }^{14} \mathrm{CO}_{2}$ and a vial with $10 \mathrm{~mL}$ of water to keep the relative humidity constant. $\mathrm{NaOH}$ traps were removed and replaced 1, 3, 7, 14, 21, 28 and 35 DAT. Three replicates were done for each herbicide and plant fraction.

At the end of incubation, four sequential extractions of soil were done: one extraction with water $-0.01 \mathrm{M} \mathrm{CaCl}_{2}$ for $24 \mathrm{~h}$, followed by three extractions for 6,15 and $6 \mathrm{~h}$ with $0.54 \mathrm{M} \mathrm{NH}_{4} \mathrm{OH}$ (Aubin and Smith, 1992). Volumes of water solution of $\mathrm{CaCl}_{2}$ or $\mathrm{NH}_{4} \mathrm{OH}$ were $50 \mathrm{~mL}$ for $10 \mathrm{~g}$ dry soil and $250 \mathrm{~mL}$ for $50 \mathrm{~g}$ dry soil. The samples were mechanically shaken at $20 \pm 1{ }^{\circ} \mathrm{C}$ in the dark and then 
centrifuged for $15 \mathrm{~min}$ at $1800 \mathrm{~g}$. NER corresponded to the radioactivity remaining in the soil after the four extractions.

\subsection{Chemical analysis}

Radioactivity content in the liquid samples ( $\mathrm{NaOH}$ traps and extracts) was measured by liquid scintillation counting using a Tricarb 2100 TR counter (Packard Instruments, Meriden, CT, USA) with external standardization and Ultima Gold XR (Packard Instruments) as a liquid scintillation cocktail. Whole $\mathrm{NaOH}$ in traps and aliquots of $1 \mathrm{~mL}$ of each extracts were mixed with $10 \mathrm{~mL}$ of the liquid scintillation cocktail.

Radioactivity in the solid samples (soil and plant) containing the NER was measured by liquid scintillation counting of the ${ }^{14} \mathrm{CO}_{2}$ evolved after combustion of triplicate $150 \mathrm{mg}$ ground dry soil or plant fractions using a Sample Oxidizer 307 (Packard Instruments). ${ }^{14} \mathrm{CO}_{2}$ was automatically absorbed in $8 \mathrm{~mL}$ of Carbo-Sorb (PerkinElmer, Boston, MA, USA) and mixed with $12 \mathrm{~mL}$ of Permafluor (PerkinElmer) as liquid scintillation cocktail.

HPLC analyses were carried out for extracts (from plants or soils) containing sufficient radioactivity $\left(>83 \mathrm{~Bq} \mathrm{~mL}^{-1}\right)$. Similar analytical methods were previously used by Mamy et al. (2005). Glyphosate and sulcotrione extracts were concentrated using a rotary evaporator (Büchi, Flawil, Switzerland) under vacuum. Concentrated samples were filtered with a syringe-regenerated cellulose filter $(0.45 \mu \mathrm{m}$, Alltech) and then acidified to $\mathrm{pH} 2$ with $\mathrm{H}_{3} \mathrm{PO}_{4}$. HPLC analyses were performed with a Waters (Milford, MA, USA) chromatography appliance (System controller 610, Autosampler 717). Radioactivity in HPLC effluents from analytical columns was detected by continuous liquid scintillation counting in Ultima-Flo AP (PerkinElmer) flo-scintillation cocktails with a Packard-Radiomatic flow detector Flo-one A-500. The counting mixture Ultima-Flo/HPLC eluent was $3 / 1 \mathrm{~mL} \mathrm{~min}^{-1}$, the mixture cell size was $0.5 \mathrm{~mL}$, and the integration period was $6 \mathrm{~s}$. Radioactivity data was calculated in disintegration per minute corrected for predetermined values of background, with automatically chemiluminescence correction. Detector worked with enable low background using the option Time-Resolved Scintillation Counting. Graphic representation allowed to obtain the radioactive chromatograms in which the surface of each chromatographic peak was integrated using the Flo-One Analysis software (version 3.65, Packard Instruments). For each peak, results were expressed in percent of total injected radioactivity, then, this percentage was applied to the radioactivity extracts to estimate the relative concentration of each compound. Glyphosate concentrated extracts were analyzed by ionic chromatography using a silica gel Adsorbosphere monomeric strong anion-exchange (SAX) column (Alltech, $5 \mu \mathrm{m}, 100 \AA$, $250 \times 4.6 \mathrm{~mm}$ ), with an isocratic elution using $\mathrm{KH}_{2} \mathrm{PO}_{4} 0.34 \mathrm{~g} \mathrm{~L}^{-1}$ adjusted to $\mathrm{pH} 2.1$ with $\mathrm{H}_{3} \mathrm{PO}_{4}$ as mobile phase at a flow of $1.0 \mathrm{~mL} \mathrm{~min}^{-1}$. In these conditions, retention times of glyphosate and AMPA were $12 \mathrm{~min}$ and $4 \mathrm{~min}$, respectively. Sulcotrione concentrated extracts were analyzed by ion-pair liquid chromatography on a silica gel end-capped Novapack C18 column (Waters, $4 \mu \mathrm{m}, 60 \AA, 250 \times 4.6 \mathrm{~mm}$ ) equilibrated with methanol/water (30/70, solvent A). The second solvent (B) was only methanol, and $0.01 \mathrm{M}$ tetra- $n$-butylammoniumchloride was added in the both A and B solvents. The elution gradient was: start with $100 \%$ of solvent $A$, reaching $55 \%$ of solvent $B$ after $10 \mathrm{~min}$, then reaching $100 \%$ of solvent B after $25 \mathrm{~min}$, both following a linear gradient. Mobile phase flow was $1.0 \mathrm{~mL} \mathrm{~min}^{-1}$. In these conditions, retention times of sulcotrione and CMBA were $18 \mathrm{~min}$ and $13 \mathrm{~min}$, respectively. The injected sample volume varied between 100 and $500 \mu \mathrm{L}$ depending on the radioactivity content.

\subsection{Data analysis}

Herbicide mineralization kinetics were described using firstorder kinetics:

$C_{t}=C_{\max }(1-\exp (-k t))$

where $C_{t}$ is the amount of mineralized herbicide (\% of initial applied dose) at time $t$ (day), $C_{\max }$ is the maximum mineralized (\% of initial applied dose), and $k$ the first-order rate constant of mineralization $\left(\right.$ day $\left.^{-1}\right)$. The values of $C_{\text {max }}$ and $k$ were determined by non-linear regression (Marquardt-Levenberg algorithm, SigmaPlot, SPSS Inc., Chicago, IL, USA).

Significant differences between treatments were determined by variance analysis with one factor. When a difference was observed, mean comparisons were done with the least significant difference (LSD) of Fisher. Difference threshold chosen was 0.05. All the calculations were done with Statgraphics 4.1 software (Manugistic Inc., Rockville, MD, USA).

\section{Results and discussion}

\subsection{Absorption, translocation and degradation of herbicides in oilseed rape and/or maize}

Seven DAT, total radioactivity recoveries in the plants (in \% of absorbed radioactivity) after washing the treated leaf were variable and ranged from $43 \%$ to $89 \%$ for glyphosate (Table 1 ) and from $46 \%$ to $72 \%$ for sulcotrione (Table 2 ). The overall balance of the

Table 1

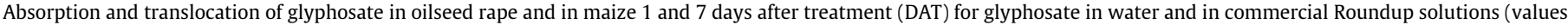
are mean \pm standard error).

\begin{tabular}{|c|c|c|c|c|c|c|c|c|}
\hline & \multicolumn{4}{|l|}{ Oilseed rape } & \multicolumn{4}{|l|}{ Maize } \\
\hline & \multicolumn{2}{|l|}{$1 \mathrm{DAT}$} & \multicolumn{2}{|l|}{$7 \mathrm{DAT}$} & \multicolumn{2}{|l|}{$1 \mathrm{DAT}$} & \multicolumn{2}{|l|}{7 DAT } \\
\hline & $\begin{array}{l}\text { Glyphosate- } \\
\text { water }\end{array}$ & $\begin{array}{l}\text { Glyphosate- } \\
\text { Roundup }\end{array}$ & $\begin{array}{l}\text { Glyphosate- } \\
\text { water }\end{array}$ & $\begin{array}{l}\text { Glyphosate- } \\
\text { Roundup }\end{array}$ & $\begin{array}{l}\text { Glyphosate- } \\
\text { water }\end{array}$ & $\begin{array}{l}\text { Glyphosate- } \\
\text { Roundup }\end{array}$ & $\begin{array}{l}\text { Glyphosate- } \\
\text { water }\end{array}$ & $\begin{array}{l}\text { Glyphosate- } \\
\text { Roundup }\end{array}$ \\
\hline \multicolumn{9}{|c|}{ Absorption (\% of applied glyphosate) } \\
\hline Whole plant & $19 \pm 16 a$ & $55 \pm 14 b$ & $56 \pm 19 b$ & $69 \pm 5 b$ & $23 \pm 16 a$ & $25 \pm 25 a$ & $15 \pm 8 a$ & $54 \pm 11 b$ \\
\hline \multicolumn{9}{|c|}{ Translocation (\% of absorbed glyphosate) } \\
\hline Treated leaf & $65 \pm 20 c$ & $97 \pm 2 d$ & $63 \pm 8 c$ & $87 \pm 9 d$ & $39 \pm 3 a b$ & $49 \pm 6 b c$ & $40 \pm 8 \mathrm{ab}$ & $30 \pm 3 a$ \\
\hline Apex & $1.0 \pm 1.2 \mathrm{ab}$ & $0.1 \pm 0.1 \mathrm{a}$ & $2.1 \pm 0.6 b$ & $0.4 \pm 0.3 a$ & $-{ }^{\mathrm{A}}$ & - & - & - \\
\hline Stem & $0.3 \pm 0.3 a$ & $0.1 \pm 0.03 a$ & $1.3 \pm 0.5 a$ & $0.8 \pm 1.0 \mathrm{a}$ & $1.2 \pm 0.4 \mathrm{a}$ & $6.8 \pm 1.9 c$ & $0.9 \pm 1.0 \mathrm{a}$ & $3.8 \pm 0.4 b$ \\
\hline Young leaves & $1.2 \pm 1.1 \mathrm{ab}$ & $1.1 \pm 0.4 \mathrm{ab}$ & $11.7 \pm 3.5 c$ & $1.8 \pm 1.4 a b$ & $0.9 \pm 0.2 \mathrm{ab}$ & $4.0 \pm 1.3 b$ & $0.5 \pm 0.2 \mathrm{a}$ & $1.9 \pm 1.5 \mathrm{ab}$ \\
\hline Old leaves & $0.2 \pm 0.1 \mathrm{a}$ & $0.4 \pm 0.4 a$ & $1.1 \pm 0.8 \mathrm{a}$ & $1.4 \pm 1.1 \mathrm{a}$ & $0.8 \pm 1.2 \mathrm{a}$ & $0.7 \pm 0.3 a$ & $0.9 \pm 0.9 \mathrm{a}$ & $3.6 \pm 1.4 b$ \\
\hline Roots & $0.4 \pm 0.3 \mathrm{ab}$ & $0.02 \pm 0.02 \mathrm{ab}$ & $1.0 \pm 0.4 \mathrm{ab}$ & $0.2 \pm 0.2 \mathrm{ab}$ & $2.2 \pm 2.3 b$ & $7.1 \pm 2.4 c$ & $0.9 \pm 0.6 \mathrm{ab}$ & $15.2 \pm 2.2 d$ \\
\hline Total & $68 \pm 18$ & $98 \pm 2$ & $77 \pm 3$ & $89 \pm 9$ & $43 \pm 2$ & $68 \pm 9$ & $43 \pm 10$ & $54 \pm 4$ \\
\hline
\end{tabular}

Values followed by the same letter are not significantly different at $P<0.05$ (test of Fischer) within the same line.

A For maize, apex was included in stem. 
Table 2

Absorption and translocation of sulcotrione in maize 1 and/or 7 days after treatment (DAT) for sulcotrione in water and in commercial Mikado solutions (values are mean \pm standard error).

\begin{tabular}{|c|c|c|}
\hline & Sulcotrione-water & Sulcotrione-Mikado \\
\hline \multicolumn{3}{|c|}{ Absorption (\% of applied sulcotrione) } \\
\hline Whole plant, 1 DAT & $7 \pm 8 a$ & $12 \pm 4 \mathrm{ab}$ \\
\hline Whole plant, 7 DAT & $19 \pm 8 b c$ & $24 \pm 4 c$ \\
\hline \multicolumn{3}{|c|}{ Translocation 7 DAT (\% of absorbed sulcotrione) } \\
\hline Treated leaf & 44 & $57 \pm 6$ \\
\hline Stem & 0.3 & $3.5 \pm 0.4$ \\
\hline Young leaves & 1.3 & $5.6 \pm 2.5$ \\
\hline Old leaves & 0.7 & $2.0 \pm 0.9$ \\
\hline Roots & 0.03 & $2.3 \pm 1.1$ \\
\hline Total & 46.3 & $72 \pm 7$ \\
\hline
\end{tabular}

Values followed by the same letter are not significantly different at $P<0.05$ (test of Fischer).

radioactivity showed low recoveries that could be explained by root exudates in soil (Coupland and Caseley, 1979; Rodrigues et al., 1982; Laitinen et al., 2007). Exudates may have been enhanced for maize because of higher photo-assimilates importation following important root development after the transplantation in pots (Gougler and Geiger, 1981). However, loss of root system when oilseed rape and maize were removed from pots can also contribute to the non-measured radioactivity. Radioactivity contained in growing substrate and the remaining roots could not be quantified (<limit of quantification).

The proportion of glyphosate absorbed in oilseed rape was higher than in maize 7 DAT: from $56 \%$ to $69 \%$ in oilseed rape, and from $15 \%$ to $54 \%$ in maize (Table 1 ). It was consistent with those observed by Hetherington et al. (1999) and Leaper and Holloway (2000). In oilseed rape, the immediate glyphosate absorption the first DAT was strongly enhanced with commercial formulation (Table 1), as was reported by Kirkwood et al. (2000) and Leaper and Holloway (2000). However, 7 DAT, glyphosate absorption was comparable when glyphosate was applied in water and in Roundup solutions. On the contrary, for maize, there was no difference in glyphosate absorption between Roundup and water solutions 1 DAT, but 7 DAT, absorption was significantly higher with Roundup (Table 1 ).

The translocation of glyphosate depended on species (Sandberg et al., 1980) and was higher in maize than in oilseed rape. For both crops, translocation began from the first DAT, which is consistent with results reported in the literature (Sprankle et al., 1975; Coupland, 1983; Hetherington et al., 1999; Leaper and Holloway, 2000), but 7 DAT, 30-87\% of absorbed glyphosate was still in the treated leaf (Table 1). The translocation happened mainly to the young parts, it is linked to the transport of photo-assimilates towards meristematic zones: the "source-sink" relationship is evidenced by the major sinks that are in apex and young leaves for oilseed rape, and stem, young leaves and roots for maize (Table 1 ). Similar trends were reported by Wyrill and Burnside (1976) and Gougler and Geiger (1981). The high amounts of glyphosate found in maize roots for Roundup (Table 1) may result from the root development after the transplantation in pots (see above) (Gougler and Geiger, 1981). Seven DAT, the amounts of glyphosate in oilseed rape treated leaf with Roundup solution were higher than the amounts observed with water solution in spite of adjuvants, probably because the stages of plant development were different when glyphosate was applied (Ahmadi et al., 1980).

Almost no degradation of glyphosate in plant was observed 7 DAT, this has also been reported in the literature (Sandberg et al., 1980; Coupland, 1983; Lorraine-Colwill et al., 2002): $99 \pm 0.1 \%$ and $89 \pm 12 \%$ of the extracted radioactivity in oilseed rape and maize respectively was glyphosate.

The absorption of sulcotrione in maize was lower than that of glyphosate, and was not significantly enhanced by adjuvants contained in the commercial Mikado (Table 2). Seven DAT, most of the absorbed ${ }^{14} \mathrm{C}$-sulcotrione remained in the treated leaf and less than $14 \%$ was translocated to other organs (Table 2 ). This is lower than amounts observed by Armel et al. (2004), however, the conditions of experiment were different (higher dose and development stage of maize in our study). The major sinks were stem, young leaves and roots, in agreement with the findings of Armel et al. (2004).

Sulcotrione in maize was almost not degraded when applied in water solution: 7 DAT, $99 \pm 1 \%$ of water soluble residues was sulcotrione and $0.4 \pm 0.7 \%$ was CMBA. However, an increase in the degradation rate was found following application with Mikado: $70 \pm 21 \%$ of water soluble residues was sulcotrione and $30 \pm 21 \%$ was CMBA. No explanation can be found since the presence of adjuvants in Mikado did not significantly modify the absorption and translocation of sulcotrione.

\subsection{Fate in soil of herbicides residues absorbed in aerial parts of oilseed rape and maize}

The amounts of herbicide and/or metabolite which will reach the soil via plant material vary according to the plant organ (the main contribution is due to lamina, Table 3 ), because of the differences in absorption and translocation, and according to the degradation of herbicide in plant. The incorporation in soil of treated oilseed rape and maize residues will mainly bring glyphosate, sulcotrione and CMBA.

As the amounts of glyphosate reaching the soil with plant residues were variable and lower than following a direct application on soil (Table 3), the effect of the dose on the fate of glyphosate was investigated. The proportion of herbicide mineralized

Table 3

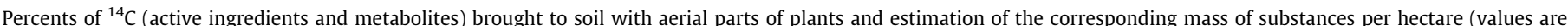
mean \pm standard error)

\begin{tabular}{|c|c|c|c|c|c|}
\hline \multirow[t]{2}{*}{ Plant } & \multirow[t]{2}{*}{ Herbicide solution } & \multicolumn{4}{|c|}{ Plant organ (\% of herbicide initially applied (estimated $\left.\mathrm{g} \mathrm{ha}^{-1}\right)^{\mathrm{a}}$ ) } \\
\hline & & Petiole & Lamina & Apex & Stem \\
\hline Oilseed rape & $\begin{array}{l}\text { Glyphosate-water } \\
\text { Glyphosate-Roundup }\end{array}$ & $\begin{array}{c}2.8 \pm 0.5(11) \\
10 \pm 6(40)\end{array}$ & $\begin{array}{l}38 \pm 23(153) \\
43 \pm 14(173)\end{array}$ & $\begin{array}{l}2.2 \pm 1.1(9) \\
1.6 \pm 0.9(6)\end{array}$ & \\
\hline Maize & $\begin{array}{l}\text { Glyphosate-water } \\
\text { Glyphosate-Roundup }\end{array}$ & & $\begin{array}{r}5.3 \pm 2.3(13) \\
13.4 \pm 1.9(33)\end{array}$ & & $\begin{array}{l}0.3 \pm 0.1(0.8) \\
7.8 \pm 1.9(20)\end{array}$ \\
\hline Maize & $\begin{array}{l}\text { Sulcotrione-water } \\
\text { Sulcotrione-Mikado }\end{array}$ & & $\begin{array}{r}3.1 \pm 0.4(3.5) \\
10.6 \pm 2.2(12)\end{array}$ & & $\begin{array}{l}0.1 \pm 0.1(0.1) \\
0.4 \pm 0.1(0.4)\end{array}$ \\
\hline
\end{tabular}

\footnotetext{
${ }^{\mathrm{a}}$ Estimated amount brought to the soil expressed in $\mathrm{g} \mathrm{ha}{ }^{-1}$ supposing one application of $1000 \mathrm{~g} \mathrm{ha}^{-1}$ of glyphosate, and $450 \mathrm{~g}$ ha ${ }^{-1}$ of sulcotrione, with foliar interception of $40 \%$ for oilseed rape and $25 \%$ for maize (FOCUS, 2000).
} 
increased significantly with higher dose (Table 4) and the extractable residues decreased; on the contrary no differences were found in the amounts of NER (data not shown). The increase in glyphosate degradation with higher dose can be related to enhanced microbial activity (Haney et al., 2000).

Mineralization kinetics of glyphosate and sulcotrione and their fate at the end of incubations are shown in Figs. 1 and 2. Mineralization was the main dissipation pathway in soil for glyphosate residues in oilseed rape and maize, but was significantly lower than controls (Figs. 1a-d and 2a-d). For both crops, the type of plant organs containing glyphosate residues influenced the fate of glyphosate $(P<0.001)$ whereas the presence of adjuvants did not (Fig. 2a-d). For oilseed rape, mineralization of glyphosate decreased as follows: control > lamina > apex, petiole; and for maize: control > lamina $>$ stem (Fig. 1a-d; Table 4). The mineralization rates in soil of glyphosate residues in plants were two to six times lower than that of control, and the maxima mineralized decreased (Table 4). The differences between the mineralization rates seem to be related to the amount of glyphosate residues (Table 3 ) and to differences in biodegradability of the different plant fractions (Nicolardot et al., 2001; Johnson et al., 2007). Glyphosate mineralization was reduced for Roundup in oilseed rape and maize for the first 4 days (Fig. 1a-d), probably because of higher penetration and translocation in plants (Table 1) linked to a decrease of glyphosate bioavailability. As glyphosate mineralization is strongly correlated to its degradation (Mamy, 2004), a two to six times increase in the persistence in soil of glyphosate included in plant can be expected.

The proportion of soil-extractable ${ }^{14} \mathrm{C}$ increased for glyphosate residues in plant materials compared to controls $(P<0.05)$ (Fig. $2 a-d$ ): from $0.1 \%$ to $24.3 \%$ in water extracts and $9.6 \%$ to $34.2 \%$ in $\mathrm{NH}_{4} \mathrm{OH}$ extracts for soil incubation with glyphosate-plants residues, and $<0.7 \%$ in water extracts and $7.3 \%$ in $\mathrm{NH}_{4} \mathrm{OH}$ extracts for control soil directly treated with glyphosate. HPLC analyses showed that $\mathrm{NH}_{4} \mathrm{OH}$ soil-extracts only contained AMPA. The water extractable residues could not be analyzed because of low radioactivity content.

The glyphosate-NER in soil after 35 days incubation increased in the order: control<lamina, petiole < apex for oilseed rape, and control < lamina, stem for maize. The very low amount of ${ }^{14} \mathrm{C}$ in stem when the glyphosate was applied in water solution (Tables 1 and 3 ) led to high variability in amounts of NER (Fig. 2a-d). The increase in NER, compared to control, is in agreement with findings of Von Wiren-Lehr et al. (1997) and may result from remobilization of released glyphosate or metabolites after plant decomposition (Von Wiren-Lehr et al., 1997), and/or from decrease in mineralization (Benoit and Barriuso, 1997).

The behavior in soil of sulcotrione residues included in maize was significantly different from the control and from that of glyphosate (Figs. 1 and 2). The fate of sulcotrione in soil was influenced by plant organs $(P<0.01)$ but not by adjuvants (Fig. 2e and f).

Mineralization increased for sulcotrione residues in maize compared to control $(P<0.001)$ (Fig. 1e and f; Table 4$)$. That could be in relation to the sulcotrione degradation in the maize: CMBA was detected in maize when sulcotrione was applied in commercial Mikado solution, thus degradation started before soil incorporation. In contrast to what was observed for glyphosate, the proportion of extractable residues decreased compared to control $(P<0.005)$. They were different for lamina and stem (Fig. 2e and f), but the low percents of sulcotrione in stem (Tables 2 and 3 ) made it impossible to obtain reproducible results. HPLC analysis was performed only for water extractable residues of control because of the low radioactivity content in other extracts. They showed that CMBA was the main compound detected: $86.7 \pm 7.3 \%$ of water extracted residues for sulcotrione application in water solution and $78.5 \pm 7.2 \%$ for Mikado.

Table 4

Mineralization rates in soil $k$ and maxima mineralized $C_{\max }$ of glyphosate and sulcotrione residues in different parts of plants (values are mean \pm standard error).

\begin{tabular}{|c|c|c|c|c|c|}
\hline Herbicide treatment & Crop & & $k\left(\right.$ day $\left.^{-1}\right)$ & $C_{\max }(\%$ of initially applied $)$ & $r^{2}$ \\
\hline \multirow[t]{2}{*}{ Glyphosate-water } & Control & Low dose & $0.148 \pm 0.015$ & $76.8 \pm 2.1$ & 0.99 \\
\hline & & High dose & $0.210 \pm 0.004$ & $76.1 \pm 3.5$ & 0.96 \\
\hline \multirow[t]{4}{*}{ Glyphosate-water } & Control & & $0.148 \pm 0.015$ & $76.8 \pm 2.1$ & 0.99 \\
\hline & Oilseed rape & Lamina & $0.086 \pm 0.004$ & $68.9 \pm 1.2$ & 0.99 \\
\hline & & Apex & $0.031 \pm 0.009$ & $79.9 \pm 14.3$ & 0.98 \\
\hline & & Petiole & $0.077 \pm 0.005$ & $55.4 \pm 1.3$ & 0.99 \\
\hline \multirow[t]{4}{*}{ Glyphosate-Roundup } & Control & & $0.190 \pm 0.026$ & $78.6 \pm 2.8$ & 0.98 \\
\hline & Oilseed rape & Lamina & $0.053 \pm 0.007$ & $78.4 \pm 5.0$ & 0.99 \\
\hline & & Apex & $0.033 \pm 0.010$ & $72.1 \pm 14.3$ & 0.98 \\
\hline & & Petiole & $0.059 \pm 0.006$ & $46.9 \pm 2.2$ & 0.99 \\
\hline \multirow[t]{3}{*}{ Glyphosate-water } & Control & & $0.197 \pm 0.037$ & $77.1 \pm 3.6$ & 0.96 \\
\hline & Maize & Lamina & $0.097 \pm 0.007$ & $60.9 \pm 1.5$ & 0.99 \\
\hline & & Stem & $0.069 \pm 0.003$ & $39.8 \pm 0.9$ & 0.99 \\
\hline \multirow[t]{3}{*}{ Glyphosate-Roundup } & Control & & $0.210 \pm 0.039$ & $76.1 \pm 3.5$ & 0.96 \\
\hline & Maize & Lamina & $0.079 \pm 0.007$ & $61.2 \pm 2.2$ & 0.99 \\
\hline & & Stem & $0.054 \pm 0.007$ & $55.6 \pm 3.6$ & 0.99 \\
\hline \multirow[t]{3}{*}{ Sulcotrione-water } & Control & & $0.078 \pm 0.013$ & $7.1 \pm 0.5$ & 0.98 \\
\hline & Maize & Lamina & $0.037 \pm 0.024$ & $40.0 \pm 15.9$ & 0.94 \\
\hline & & Stem & $0.040 \pm 0.017$ & $25.3 \pm 6.1$ & 0.96 \\
\hline \multirow[t]{3}{*}{ Sulcotrione-Mikado } & Control & & $0.045 \pm 0.009$ & $7.7 \pm 0.9$ & 0.98 \\
\hline & Maize & Lamina & $0.024 \pm 0.003$ & $59.2 \pm 4.7$ & 0.99 \\
\hline & & Stem & $0.045 \pm 0.009$ & $60.1 \pm 6.2$ & 0.99 \\
\hline
\end{tabular}



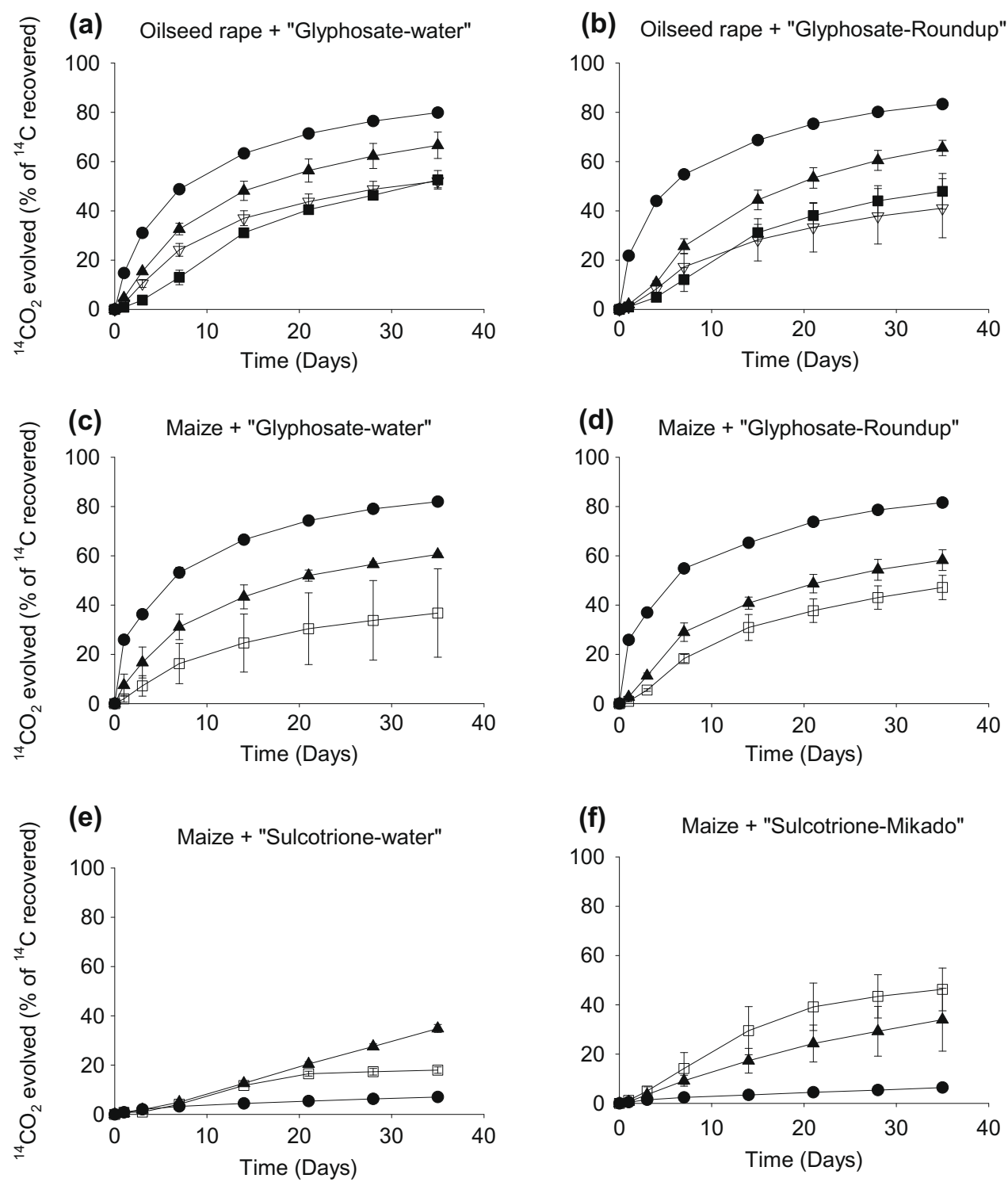

- Control ^ Lamina $\nabla$ Petiole - Apex $\square$ Stem

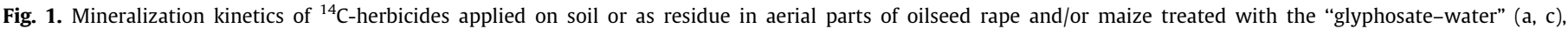

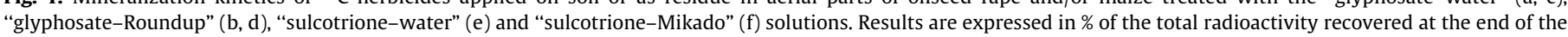
incubations (standard deviations are shown only when larger than symbols).

The amounts of sulcotrione NER in soil after 35 days incubation increased as follows: control < lamina < stem. As for glyphosate, they may result from remobilization of sulcotrione or metabolites released in soil after plant decomposition (Von Wiren-Lehr et al., 1997).

The differences in the fate in soil of glyphosate and sulcotrione residues in plant may be due to their different pathways of metabolism (non-selective/selective herbicide) as glyphosate was not degraded in plant contrary to sulcotrione in maize.

\section{Conclusions}

The modification of herbicides degradation in soil following their absorption by plants may change the risk of environmental contamination: the risk of leaching increase for AMPA (because of an increase in the soil-extractable amounts), and decrease for sulcotrione and CMBA. The increase in NER for both herbicides and crops enhances the amounts of substances which could be released and could lead to further environmental contamination (Barriuso et al., 2008). Finally, the persistence of glyphosate in soil could increase from two to six times. These modifications should be taken into account in the modeling of pesticide fate, especially for the risks assessment for pesticides registration.

Furthermore, the case of glyphosate-resistant crops should be considered: crops residues which will be restituted into the soil will be substantially higher than those of weeds, now glyphosate will accumulate in crops because of the genetic modification (Dill, 2005). This could increase the amounts of glyphosate brought to soil and consequently the risks of pollution by this herbicide. 
(a)

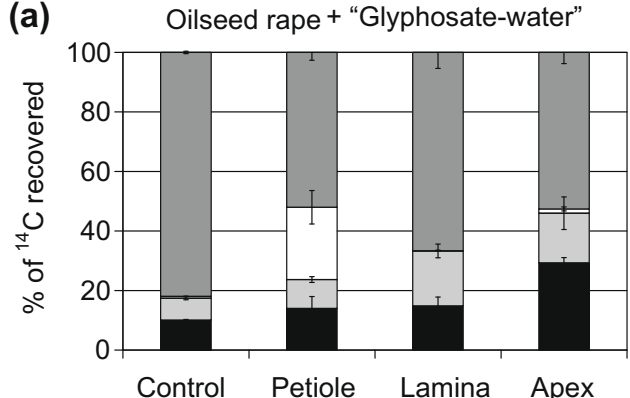

(c)

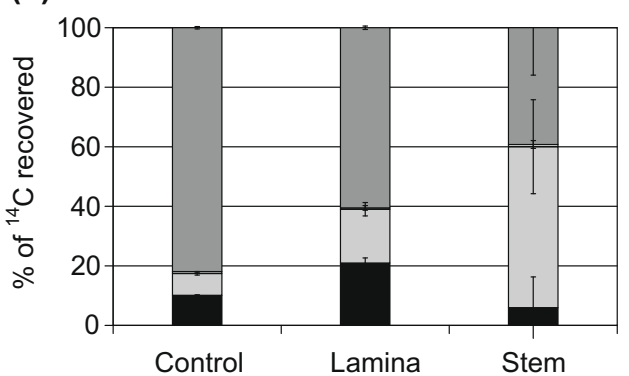

(e)

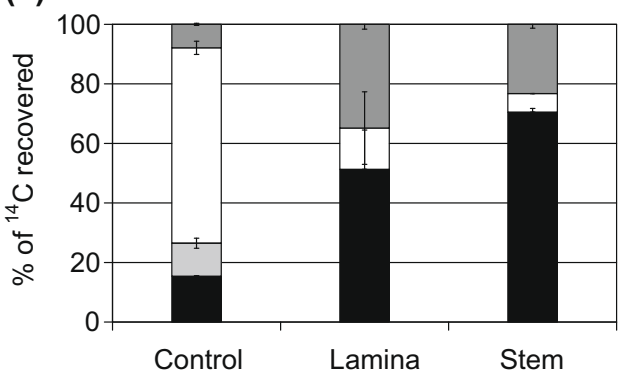

(b) Oilseed rape + "Glyphosate-Roundup"

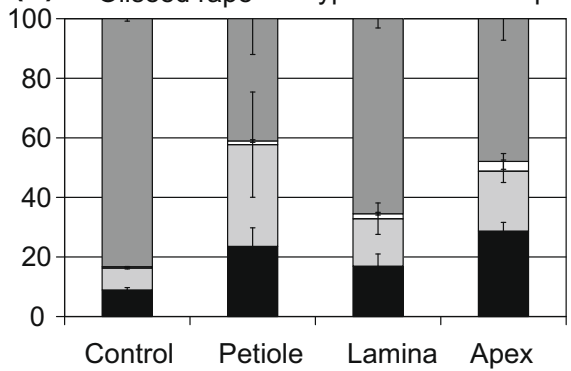

(d) Maize + "Glyphosate-Roundup"

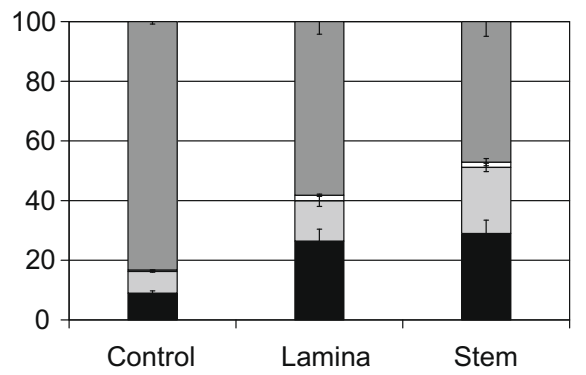

(f) Maize + "Sulcotrione-Mikado"

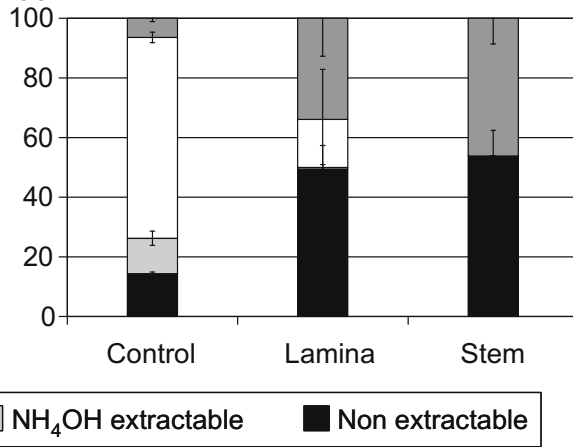

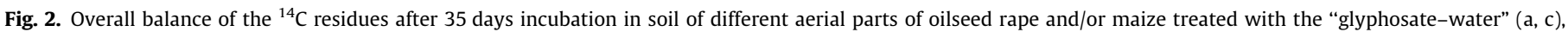

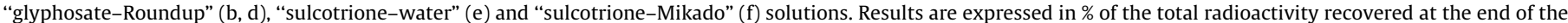
incubations.

\section{Acknowledgements}

The authors are grateful to Professor Benoît Gabrielle for his constructive comments and for the financial support through a project in the CNRS (Centre National de la Recherche Scientifique) programme "Impact des biotechnologies sur le bilan environnemental des systèmes agricoles». The authors also acknowledge the Laboratoire Sols et Environnement (ENSAIA-INPL/INRA) for supplying ${ }^{14} \mathrm{C}$-sulcotrione.

\section{References}

Ahmadi, M.S., Haderlie, L.C., Wicks, G.A., 1980. Effect of growth stage and water stress on barnyardgrass (Echinochloa crus-galli) control and on glyphosate absorption and translocation. Weed Sci. 28, 277-282.

Armel, G.R., Mayonado, D.J., Hatzios, K.K., Wilson, H.P., 2004. Absorption and translocation of SC-0051 in corn and soybean. Weed Technol. 18, 211-214.

Aubin, J.A., Smith, A.E., 1992. Extraction of $\left[{ }^{14} \mathrm{C}\right]$ glyphosate from Saskatchewan soils. J. Agr. Food Chem. 40, 1163-1165.

Barriuso, E., Benoit, P., Dubus, I.G., 2008. Formation of pesticide nonextractable (bound) residues in soil: magnitude, controlling factors and reversibility. Environ. Sci. Technol. 42, 1845-1854.

Benoit, P., Barriuso, E., 1997. Fate of ${ }^{14} \mathrm{C}$-ring labeled 2,4-D, 2,4-dichlorophenol and 4-chlorophenol during straw composting. Biol. Fert. Soils 25, 53-59.
Caseley, J.C., Coupland, D., 1985. Environmental and plant factors affecting glyphosate uptake, movement and activity. In: Grossbard, E., Atkinson, D. (Eds.), The Herbicide Glyphosate. Butterworths, London, UK, pp. 92-123.

Chamel, A., Gaillardon, P., Gauvrit, C., 1991. La pénétration foliaire des herbicides. In: Scalla, R. (Ed.), Les Herbicides. Mode d'Action et Principes d'Utilisation. INRA Paris, France, pp. 7-49.

Cherrier, R., Perrin-Ganier, C., Schiavon, M., 2004. Degradation of sulcotrione in a brown soil amended with various organic matters. Agronomie 24, 29-33.

Coupland, D., 1983. Influence of light, temperature and humidity on the translocation and activity of glyphosate in Elymus repens (=Agropyron repens). Weed Res. 23, 347-355.

Coupland, D., Caseley, J.C., 1979. Presence of ${ }^{14} \mathrm{C}$ activity in root exudates and guttation fluid from Agropyron repens treated with ${ }^{14} \mathrm{C}$-labelled glyphosate. New Phytol. 83, 17-22.

Dill, G.M., 2005. Glyphosate-resistant crops: history, status and future. Pest Manag. Sci. 61, 219-224.

FOCUS, 2000. FOCUS groundwater scenarios in the EU review of active substances. Report of the FOCUS Groundwater Scenarios Workgroup, EC Document Reference Sanco/321/2000 rev.2, 202 p.

Franz, J.E., 1985. Discovery, development and chemistry of glyphosate. In: Grossbard, E., Atkinson, D. (Eds.), The Herbicide Glyphosate. Butterworths, London, UK, pp. 3-17.

Gauvrit, C., 1996. Efficacité et Sélectivité des Herbicides. INRA, Paris.

Gougler, J.A., Geiger, D.R., 1981. Uptake and distribution of N-phosphonomethylglycine in sugar beet plants. Plant Physiol. 68, 668-672.

Grangeot, M., Chauvel, B., Gauvrit, C., 2006. Spray retention, foliar uptake and translocation of glufosinate and glyphosate in Ambrosia artemisiifolia. Weed Res. $46,152-162$. 
Haney, R.L., Senseman, S.A., Hons, F.M., Zuberer, D.A., 2000. Effect of glyphosate on soil microbial activity and biomass. Weed Sci. 48, 89-93.

Hetherington, P.R., Reynolds, T.L., Marshall, G., Kirkwood, R.C., 1999. The absorption, translocation and distribution of the herbicide glyphosate in maize expressing the CP-4 transgene. J. Exp. Bot. 50, 1567-1576.

Johnson, J.M.F., Allmaras, R.R., Reicosky, D.C., 2006. Estimating source carbon from crop residues, roots and rhizodeposits using the National Grain-Yield database. Agron. J. 98, 622-636.

Johnson, J.M.F., Barbour, N.W., Lachnicht Weyers, S., 2007. Chemical composition of crop biomass impacts its decomposition. Soil Sci. Soc. Am. J. 71, 155-162.

Kirkwood, R.C., Hetherington, R., Reynolds, T.L., Marshall, G., 2000. Absorption, localisation, translocation and activity of glyphosate in barnyardgrass (Echinochloa crus galli (L.) Beauv): influence of herbicide and surfactant concentration. Pest Manag. Sci. 56, 359-367.

Laitinen, P., Rämö, S., Siimes, K., 2007. Glyphosate translocation from plants to soil does this constitute a significant proportion of residues in soil? Plant Soil 300 51-60.

Leaper, C., Holloway, P.J., 2000. Adjuvants and glyphosate activity. Pest Manag. Sci. $56,313-319$.

Lorraine-Colwill, D.F., Powles, S.B., Hawkes, T.R., Hollinshead, P.H., Warner, S.A.J., Preston, C., 2002. Investigations into the mechanism of glyphosate resistance in Lolium rigidum. Pestic. Biochem. Physiol. 74, 62-72.

Mamy, L., 2004. Comparaison des Impacts Environnementaux des Herbicides à Large Spectre et des Herbicides Sélectifs: Caractérisation de leur Devenir dans le Sol et Modélisation. Ph.D. Thesis, Institut National Agronomique Paris-Grignon, Paris. <http://www.inra.fr/ea/fichier_these/MAMY-L.pdf>.

Mamy, L., Barriuso, E., Gabrielle, B., 2005. Environmental fate of herbicides trifluralin, metazachlor, metamitron and sulcotrione compared with that of glyphosate, a substitute broad spectrum herbicide for different glyphosateresistant crops. Pest Manag. Sci. 61, 905-916.
Marshall, G., Kirkwood, R.C., Martin, D.J., 1987. Studies on the mode of action of asulam, aminotriazole and glyphosate on Equisetum arvense L. (field horsetail). II: the metabolism of $\left[{ }^{14} \mathrm{C}\right]$ asulam, $\left[{ }^{14} \mathrm{C}\right]$ aminotriazole and $\left[{ }^{14} \mathrm{C}\right]$ glyphosate. Pestic. Sci. 18, 65-77.

Nicolardot, N., Recous, S, Mary, B., 2001. Simulation of $\mathrm{C}$ and $\mathrm{N}$ mineralisation during crop residue decomposition: a simple dynamic model based on the $\mathrm{C}: \mathrm{N}$ ratio of the residues. Plant Soil 228, 83-103.

Rodrigues, J.J.V., Worsham, A.D., Corbin, F.T., 1982. Exudation of glyphosate from wheat (Triticum aestivum) plants ant its effects on interplanted corn (Zea mays) and soybeans (Glycine max). Weed Sci. 30, 316-320.

Rueppel, M.L., Brightwell, B.B., Schaefer, J., Marvel, J.T., 1977. Metabolism and degradation of glyphosate in soil and water. J. Agr. Food Chem. 25, 517-528.

Sandberg, C.L., Meggitt, W.F., Penner, D., 1980. Absorption, translocation and metabolism of ${ }^{14} \mathrm{C}$-glyphosate in several weed species. Weed Res. 20, 195-200.

Smith, A.E., Aubin, A.J., 1993. Degradation of ${ }^{14}$ C-glyphosate in Saskatchewan soils. Bull. Environ. Contam. Tox. 50, 499-505.

Sprankle, P., Meggit, W.F., Penner, D., 1975. Absorption, action and translocation of glyphosate. Weed Sci. 23, 235-240.

Ter Halle, A., Drncova, D., Richard, C., 2006. Phototransformation of the herbicide sulcotrione on maize cuticular wax. Environ. Sci. Technol. 40, 2989-2995.

Torstensson, L., 1985. Behaviour of glyphosate in soils and its degradation. In: Grossbard, E., Atkinson, D. (Eds.), The Herbicide Glyphosate. Butterworths, London, UK, pp. 137-150.

Von Wiren-Lehr, S., Komoßa, D., Glaßgen, W.E., Sandermann Jr., H., Scheunert, I., 1997. Mineralization of $\left[{ }^{14} \mathrm{C}\right]$-glyphosate and its plant-associated residues in arable soils originating from different farming systems. Pestic. Sci. 51, 436-442.

Wilson, J.S., Foy, C.L., 1990. Weed control in no-tillage and conventional corn (Zea mays) with ICIA-0051 and SC-0774. Weed Technol. 4, 731-738.

Wyrill, J.B., Burnside, O.C., 1976. Absorption, translocation and metabolism of 2,4-D and glyphosate in common milkweed and hemp dogbane. Weed Sci. 24, 557-566. 